\title{
Optical micromanipulation of freestanding microstructures with embedded waveguides
}

Palima, Darwin; Bañas, Andrew Rafael; Vizsnyiczai, Gaszton; Kelemen, Lóránd; Aabo, Thomas; Ormos, Pál; Glückstad, Jesper

Published in:

Optics in the Life Sciences Congress Technical Digest

Publication date:

2013

Document Version

Publisher's PDF, also known as Version of record

Link back to DTU Orbit

Citation (APA):

Palima, D., Bañas, A. R., Vizsnyiczai, G., Kelemen, L., Aabo, T., Ormos, P., \& Glückstad, J. (2013). Optical micromanipulation of freestanding microstructures with embedded waveguides. In Optics in the Life Sciences Congress Technical Digest (pp. TM4D.6). Optical Society of America.

\section{General rights}

Copyright and moral rights for the publications made accessible in the public portal are retained by the authors and/or other copyright owners and it is a condition of accessing publications that users recognise and abide by the legal requirements associated with these rights.

- Users may download and print one copy of any publication from the public portal for the purpose of private study or research.

- You may not further distribute the material or use it for any profit-making activity or commercial gain

- You may freely distribute the URL identifying the publication in the public portal 


\title{
Optical micromanipulation of freestanding microstructures with embedded waveguides
}

\author{
Darwin Palima, ${ }^{1, *}$ Andrew Rafael Bañas, ${ }^{1}$ Gaszton Vizsnyiczai, ${ }^{2}$ \\ Lóránd Kelemen, ${ }^{2}$ Thomas Aabo, ${ }^{1}$ Pál Ormos, ${ }^{2}$ and Jesper Glückstad ${ }^{1}$,** \\ ${ }^{1}$ DTU Fotonik, Dept. of Photonics Engineering, \\ Technical University of Denmark, DK-2800, Kgs. Lyngby, Denmark \\ ${ }^{2}$ Institute of Biophysics, Biological Research Centre, \\ Hungarian Academy of Sciences, Szeged H-6701, Hungary \\ *dazp@fotonik.dtu.dk, .**jesper.gluckstad@fotonik.dtu.dk \\ www.ppo.dk
}

\begin{abstract}
Optically micromanipulated waveguides can be arbitrarily positioned and oriented for targeted light delivery. At the same time, controlled light deflection in designed waveguides can be exploited to exert optical forces for new optical micromanipulation modalities.

OCIS codes: (170.4520) Optical confinement and manipulation; (220.4000) Microstructure fabrication; (230.7370) Waveguides.
\end{abstract}

\section{Introduction}

Contemporary micro- and nanofabrication technologies enable the design and fabrication of novel synthetic structures, which can be imbibed with various features. The use of controlled optical forces enables the versatile mechanical actuation of these microstructures for various applications [1].

Our recent work focuses on the design and two-photon fabrication of free-standing waveguides, which are amenable to optical trapping and optical micromanipulation. On the one hand, free-standing waveguides can be optically positioned and oriented for targeted light delivery in three dimensions [2]. On the other hand, waveguides are highly suitable for controlling light deflection, which can be exploited to exert optical forces on the structures containing the waveguides [3]. Hence, embedded waveguides onto free-standing microstructures can serve as new handles for optical trapping and micromanipulation.

\section{Results}

Figure 1 illustrates two complementary modes for the optical micromanipulation of synthetic freestanding microstructures with embedded waveguides. In Fig. 1(a), a two-photon-polymerized microstructure is optically trapped via spherical handles to position and orient its embedded waveguide, which can then tap light from an incident broad beam and redirect illumination onto a localized target. In Fig. 1(b), the light deflections in its embedded waveguide exert force on the microstructure to move it along a trajectory defined by the illumination pattern. These complementary modes can have applications for optical excitation, sensing and micromanipulation.

(a)

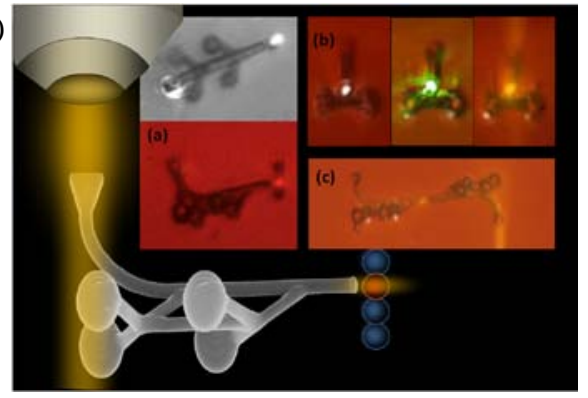

(b)

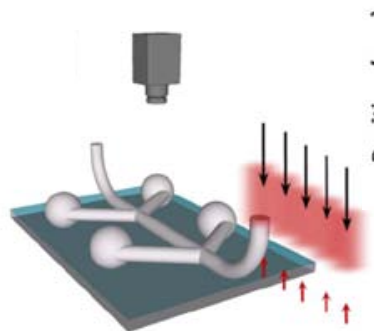

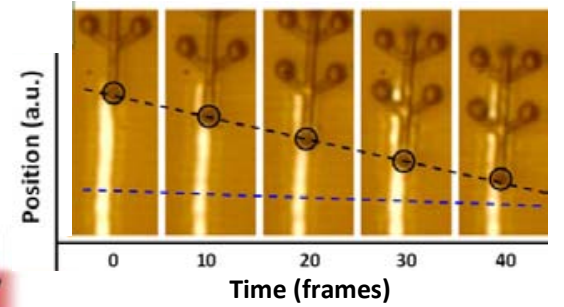

Time (frames)

Fig. 1. Optical micromanipulation of free-standing waveguides: (a) A free-standing waveguide can be optically positioned and oriented for targeted light delivery [2]; (b) Guided light deflections can exert forces on waveguide to actuate the structure containing the waveguide [3].

[1] D. Palima, and J. Glückstad, "Gearing up for optical microrobotics: micromanipulation and actuation of synthetic microstructures by optical forces," Laser \& Photon. Rev. advance online publication (7 Jan 2013). doi: 10.1002/lpor.201200030.

[2] D. Palima, A. R. Bañas, G. Vizsnyiczai, L. Kelemen, P. Ormos, and J. Glückstad, "Wave-guided optical waveguides," Opt. Express 20, $2004-$ 2014 (2012).

[3] D. Palima, A.R. Bañas, G. Vizsnyiczai, L. Kelemen, T. Aabo, P. Ormos, and J. Glückstad, "Optical forces through guided light deflections," Opt. Express 21, 581-593 (2013). 